\title{
Effects of Self Message Type and Incidental Pride Type on Product Purchase Intention*
}

\section{제품의 구매의도에 대한 자아 메시지의 유형과 환경적 프라이드의 유형의 효과}

\author{
Nak-Hwan $\mathrm{CHOI}($ 최낙환)**
}

Received: September 06, 2019. Revised: September 18. Accepted: October 05. 2019.

\section{Abstract}

Purpose - Current study aimed at investigating the effects of the choice easiness as a thought triggered at the time of making decision and the goal achievement emotion as a prediction of how consumers feel in the state of achieving consumption goal on brand purchase intention. And It also explored moderation role of incidental pride type such as ambient hubris pride and ambient authentic pride felt before the event in the effects of message type such as self-verifying message and self-enhancing message on the choice easiness and the goal achievement emotion.

Research design, data, and methodology - Message type was divided into self-verifying message and self-enhancing message. Incidental pride type was divided into hubris and authentic pride. Smart mobile phone was selected for empirical study. And the experiment was performed with 2(pride type: hubristic versus authentic) $\times 2$ (message type: self-verifying message versus self-enhancing message) between-subjects design. Questionnaires from 215 undergraduate students were used to test hypotheses by Macro process model 7. The hypotheses were tested at each of self-verifying message group and self-enhancing message group.

Results - First, both choice easiness and goal achievement emotion positively influenced on the purchase intention at both self-verifying message group and self-enhancing message group. Second, at self-verifying message group, the positive effects of self verification on both choice easiness and goal achievement emotion were higher to the customers under incidental hubris pride than to those under incidental authentic pride customers. Third, at self-enhancing message group, the positive effects of self enhancement on goal achievement emotion were higher to the customers under incidental authentic pride than to those under incidental hubris pride. However, at self-enhancing message group, the positive effects of self enhancement on choice easiness (goal achievement emotion) were not higher (higher) to the customers under incidental authentic pride than to those under incidental hubris pride.

Conclusions - Focusing on the results of this study, to promote their brand purchase intention, brand managers should use self-enhancing message to induce goal achievement emotion from incidental authentic pride customers. And the brand managers should develop and use self-verifying message to induce choice easiness as well as goal achievement emotion from hubris pride customers, which in turn, promote their brand purchase intention.

Keywords: Choice Easiness, Goal Achievement Emotion, Message Type, Purchase Intention, Pride Type.

JEL Classifications: C83, L81, M31, P46.

* This research was supported by "Research Base Construction Fund Support Program" funded by Chonbuk National University in 2019.

** Professor, Department of Business Administration, Chonbuk National University, Korea. Tel: +82-63-270-2998, E-mail: cnh@jbnu.ac.kr

(1) Copyright: Korean Distribution Science Association (KODISA)
This is an Open Access article distributed under the terms of the Creative Commons Attribution Non-Commercial License (https://creativecommons.org/licenses/by-nc/4.0/) which permits unrestricted non-commercial use, distribution, and reproduction in any medium, provided the original work is properly cited.

\section{1. 서론}

소비자는 즉흥적인 단기의 목적 보다 자신의 이상이나 가 치, 그리고 사회적 기대에 부합하려는 자아통제(self control)를 하여 장기적인 목적을 추구하는 행동을 한다(Baumeister, 2008; Gailliot, Gitter, Baker, \& Baumeister, 2012). 의식적인 노력이 투여되는 자아통제는 장기목적 또는 사회적으로 수용될 수 있는 행동을 추구하게 하고, 장기적으로 집단 멤버십을 촉 진하는 기능을 하여(Baumeister, Vohs, \& Tice, 2007), 현재의 
선택을 기존의 선호도 또는 즉흥적인 단기의 목적보다 장기목 적의 관점에서 결정한다(Muraven, Tice, \& Baumeister, 1998).

기존의 연구는 브랜드의 자아 일치성, 장기목적과 제품의 상징적 의미, 기분(mood) 상태 등에 초점을 두고 진행되었다. 제품이나 브랜드와 소비자의 자아 간의 일치성을 상징적 일치 성과 기능적 일치성으로 구분하였으며(Sirgy et al., 1997), 주 로 자아 일치성의 효과에 관한 연구를 수행하였다. 자아 일치 성의 브랜드 선호도와 만족도 효과, 브랜드 태도(Hosany \& Martin, 2012; Marshall, Na, State, \& Deuskar, 2008) 효과를 탐색하였고, 또 소비자의 자아개념이 위협을 받으면 위협을 보 상하는 방법으로 자아 개념과 상징적으로 일치하는 제품이나 서비스를 소비하는 성향(Mandel, Rucker, Levav, \& Galinsky, 2017), 자아 일치성이 구매의도, 충성도(He \& Mukherjee, 2007; Jamal \& Al-Marri, 2007; Mazodier \& Merunka, 2012; Usakli \& d Baloglu, 2011)의 예측성을 연구하여, 자아 일치성의 효과 에 초점을 두고 있다. 또 기존의 연구는 소비자의 장기목적에 주의하여 진행되었다. 쾌락적 소비에서 자아를 규제하여 (Fishbach, Friedman, \& Kruglanski, 2003), 탐닉재와 실용재의 선택 간의 갈등에서, 장기목적이 활성화되면 자아통제가 소비 자의 기억에서 현저하게 되고, 실용재보다 탐닉 제품을 선택할 가능성은 낮아진다(Choi, 2016). 소비 제품이나 브랜드의 상징 적 의미가 활성화(semantic activation)되고 제품이나 브랜드의 의미가 소비자 자아와 일치하면, 구매하고 소비하여 타인에게 자신을 표현할 수 있음을 보여주고 있다. 또한 긍정적인 기분 상태의 소비자는 중요 속성에 더 주의하는 체계적 정보처리를 하여 중요한 속성들 간의 상쇄에서 어려움을 느끼고 선택 결 정을 지연하는 경향이 있으며(Etkin \& Ghosh, 2018), 감정적인 의사결정자는 재무적 의사결정을 싫어하고 회피하는 성향이 있다(Park \& Sela, 2018).

그런데 소비자의 자아통제 관점에서 마케터가 어디에 초점 을 두고 접근해야 브랜드의 구매의도를 더욱 촉진할 수 있을 까? 소비자의 자아의 입증과 자아의 향상 중에서 어디에 초점 을 두고 접근해야 하는가? 기존의 연구는 자아의 입증과 자아 의 향상에서 서로 다른 자아 메시지 유형의 관점에서 제품이 나 브랜드에 어떻게 접근해야 소비자를 설득할 수 있는가에 대하여 주의하지 못하였고, 사전에 느끼는 프라이드의 유형에 따라 어떤 자아 메시지 유형이 소비자를 더 설득할 수 있는가 에 대한 연구가 부족하였다. 오만성 프라이드는 소비자의 성공 에 안정적이고 불변적 자질(traits)이 귀인되어 느껴지는 감정 이고, 진정성 프라이드는 불안정한 가변적인 노력(efforts)이 귀 인 되어 느껴지는 감정이다. 그리고 오만성 프라이드는 방어적 자아 존중감과 나르시시즘에서 나타나는 불안정한 자아가치 (unstable self-worth)와 관련되고, 진정성 프라이드는 안정적인 자존감(stable self-esteem)과 진정성 등의 자아가치 및 자아 청렴성과 관련된다 (Tracy, Cheng, Martens, \& Robins, 2011). 그리고 소비자는 자기 자신을 좋게 생각하려고 노력한다는 관 점에서 자존감(self-esteem)은 기질(traits)이기보다 모티베이션 요 소이며, 자존감 동기는 긍정적인 성과에 대한 접근동기인 자아향 상(self-enhancement)과 실패나 손실의 회피동기인 자아보호 (self-protection)로 구분된다(Tice \& Masicampo, 2008). 따라서 브랜드의 자아와 관련된 메시지는 소비자의 성과에 기초한 자아 향상 메시지와 실패나 손실이 없는 일관된 성과를 도출하는 안정 적인 기질에 초점을 둔 자아입증 메시지로 유형화할 수 있다.

메시지 유형 간에 브랜드의 선택결정용이성과 브랜드의 이 용에서 느낄 수 있는 목적성취감정에 미치는 영향정도가 달라
질 수 있고, 자아가치가 불안정하고 사전에 오만성 프라이드를 느끼는 소비자에게 브랜드 메시지가 자아의 입증성을 촉진하 여 선택결정용이성과 목적성취감정을 더 지각하게 하여 설득 할 수 있다. 성과의 진정성의 가치를 소구하는 자아향상성이 진정성 프라이드를 사전에 느끼는 소비자가 선택결정용이성과 목적성취감정을 더 지각하게 하여 설득할 수 있어서, 자아 메 시지의 유형의 브랜드 구매의도 효과를 사전에 느낀 프라이드 의 유형이 조절할 수 있다. 따라서 브랜드 메시지 유형을 자아 입증성 메시지와 자아향상성 메시지로 구분하여, 선택결정용이 성과 목적성취감정에 대한 영향을 탐색하고, 브랜드의 구매의 도 효과를 식별할 필요가 있으며, 선택결정용이성과 목적의 성 취감정에 대한 자아 메시지의 유형별 영향이 사전에 느낀 프 라이드의 유형에 의해 조절됨을 탐색할 필요가 있다.

따라서 이 연구의 목적을 다음과 같이 설정한다. 첫째, 브랜 드의 구매의도에 선택결정용이성과 목적성취감정의 영향을 탐 색한다. 둘째, 현재자아의 입증에 초점을 둔 메시지에서 자아 입증성의 지각과 자아의 향상에 초점을 둔 메시지에서 자아향 상성의 지각이 소비자의 브랜드의 선택결정용이성과 소비목적 의 성취감정에 영향을 미치는 정도를 식별한다. 셋째, 자아 메 시지의 유형별 지각되는 자아입증성과 자아향상성의 선택결정 용이성과 목적의 성취감정에 대한 영향을 사전에 느낀 프라이 드의 유형이 조절함을 탐색한다.

\section{2. 이론적 배경과 가설의 설정}

\section{1. 선택결정용이성 및 목적성취감정과 구매의도}

Anderson(2003)은 선택 의사결정에서 어려움을 과업 복잡 성, 속성 간의 상쇄(trade-off) 어려움 그리고 의사결정자의 선 호 불확실성으로 설명한다. 경쟁대체안의 수와 속성의 수가 많 고, 속성 값의 분포가 대체안들 간에 유사하면, 정보가 소비자 에게 과부하 되고 불확실성의 수준이 높게 되어 의사결정이 어렵게 된다(Lurie, 2004). 그리고 경쟁대체안 간에 속성 값들 이 부정적 상관관계가 있어서 소비자가 특정 목적에 부합한 속 성에서 우수한 선택안을 결정하면 다른 중요속성에서 진단성이 있는 다른 목적을 희생하게 된다(Bettman, Johnson, Luce, \& Payne, 1993). 예를 들면, 경쟁대체안의 가격과 품질 간에 부 정적 상관관계는 가격속성에 가중치를 주어 선택안을 결정하 면, 품질속성에 가중치가 약화되어 품질목적을 희생하게 된다. 최근에 Etkin and Ghosh(2018)는 중립적 기분의 소비자 보다 긍정적인 기분상태의 소비자가 중요 속성에 더 주의하여 대체 안들 간 중요 속성의 상쇄에서 어려움을 많이 겪고 선택 결정 을 지연하는 경향이 있음을 탐색하였다. 의사결정지연에서 상 쇄어려움의 매개역할을 검증하였다. 그리고 그들은 긍정적인 기분의 소비자는 자신에게 중요한 속성에 주위를 더 하게 되 어 유리스틱(heuristic) 정보처리보다 체계적(systematic) 정보 처리를 함을 실증하였다. 그리고 과업 맥락의 차이와 목적체계 의 명확성정도에서 개인 간의 차이가 선호도 불확실성이 달라 지게 하고(Coupey, Irwin, \& Payne, 1998), 속성 간의 가중치 와 상쇄에서 어려움을 더욱 겪게 할 수 있다.

그러나 목적이 명확하고 선호도가 잘 정리되어 속성 간의 이상적인 조합이 용이하게 되면 속성 간의 상쇄에서 어려움이 감소되고 선택이 용이해진다(Chernev, 2003). 소비목적이 명확 
하고 선호도가 잘 정리되면, 제품소비목적에 진단적인 속성과 그 속성에 대한 가중치가 안정적이게 되고 속성 간의 상쇄가 용이하여 선택결정의 용이성이 확보되고 제품의 구매가 촉진 될 수 있다.

H1: 선택결정의 용이성은 구매의도에 긍정적 영향을 미친다.

중요한 대체안의 선택과정에서 소비자가 부정적 성과의 가 능성을 지각하면 소비자는 공포 불안 낙담과 같은 감정을 느 낄 수 있지만(Loewenstein, Weber, Hsee, \& Welch, 2001), 소 비자의 소비 목적이 잘 정리되어 안정적이면 하나의 대체안을 숙고하는 과정을 거치는 동안에 선호도가 명확하게 되어 소비 목적의 성취감정(goal achievement affect)을 느낄 수 있다.

고전적 이론으로서 확산 활성화(spreading of activation) 이 론(Anderson \& Bower, 1973)은 하나의 단위가 기억에서 활성 화되면 연상 통로를 따라서 다른 구성 단위로 연결되어 흘러 감을 설명했다. 그리고 목적체계이론(Fishbach, Shah, \& Kruglanski, 2004)은 소비자의 인지시스템에서 수단단위와 목 적단위 간에 인지적 연결강도는 단위 간의 특성(properties)의 전이에 영향을 미침을 설명한다. 따라서 목적 시스템에서 목적 달성의 감정이 목적달성의 수단으로 전이 될 수 있다. 목적달 성의 활성화로 긍정적 감정이나 가치가 표상될 때 목적개념이 더욱 수용될 수 있고, 목적성취감정의 연상이 수단행동의 구매 또는 소비를 촉진할 수 있다.

브랜드의 구매와 소비로 목적성취에서 느겨질 수 있는 감정 이 브랜드에 전이되어 구매의도에 긍정적인 영향을 미칠 수 있다. 목적 시스템의 기능으로 브랜드의 소비에서 목적의 성취 감정을 강하게 느낄 수 있고, 그 목적성취에서 느껴지는 긍정 감정이 의미적 연상을 넘어서 브랜드에 전이되어 구매를 자극 할 수 있다. 소비자의 인지시스템에서 브랜드의 사용목적의 달 성에서 느겨지는 감정이 브랜드에 전이되어 브랜드의 구매의 도를 촉진할 수 있다.

H2: 브랜드소비의 목적성취감정은 구매의도에 긍정적 영향 을 미친다.

\section{2. 자아와 관련된 브랜드메시지의 유형}

자아개념은 자신에 대한 총체적인 생각이나 느낌으로 정의 된다(Rosenberg, 1979). 따라서 자아개념은 객관적인 실체의 개념이기보다는 자신에 대한 주관적인 지각 개념이고 평가개 념으로서, 자신의 능력, 한계, 외모, 특성, 퍼스낼리티를 포함 하는 개념이다(Graeff, 1996). 그리고 자신에 대한 주관적인 견 해(subjective self view)로서 아이덴티티(identity)는 소비자가 서로 다른 많은 범주와 동일시될 수 있다는 사고에 기초 하여 정의되는데, 소비자가 선택이나 소유에서 자신과 관련시키는 특정 범주표찰(category label)이 그 소비자의 아이덴티티가 된 다(Reed, Forehand, Puntoni, \& Warlop, 2012). 이러한 아이덴 티티는 상대적으로 안정적이며 객관적이지만 일시적이고 유동 적이고 주관적일 수도 있다. 소비자의 아이덴티티의 범주표찰은 소비자 자신이 어떤 사람으로 보이고 생각되고 느끼고 행동하 는가에 대한 심리적 표상을 의미하는데(Oyserman, 2009), 아 이덴티티의 정립과정에서 중요한 것은 소비자가 어떤 범주표 찰을 자기 자신에게 투입해서 자신이 그런 유형의 사람이 되 는 과정이다.
이러한 아이덴티티의 과정은 자신의 상태, 주변의 환경적 맥 락에 따라 유동적일 수 있는데, 소비자에게 어떤 아이덴티티가 현저하게 되면, 그 소비자는 그 아이덴티티와 관련해서 행동을 하려 하고, 실제 자아와 이상 자아 간의 거리가 크게 지각되면 소비자는 이상자아에 도달하려는 노력을 하게 된다(Higgins, 1987). 특정 아이덴티티가 소비자 자아의 시금석이 되면, 그 아이덴티티에 도달하려는 행동을 하게 된다. 이러한 아이덴티 티의 추구는 소비자가 자기 자신을 스스로 생각하는 것과 같게 타인도 자기 자신을 생각하게 할 수 있는 행동을 하여 타인에 게 자아를 입증하거나 향상시킬 수 있는 과정을 거치게 한다.

소비자는 자신에게 부여하는 범주표찰과 어울리는 제품이나 브랜드를 탐색하여 선택하는데, 여기서 소비자의 아이덴티티 입증과 향상 원리를 생각할 수 있다. 외부 환경에서 유입되는 피드백 브랜드정보가 자신의 실제적 또는 이상적인 아이덴티 티를 표상할 수 있는가에 따라 다르게 처리 된다. 제품이나 브 랜드에 관한 정보가 그 제품이나 브랜드의 사용이 자신의 실 제적 자아를 표현하게 한다면, 자신의 아이덴티티가 입증된다 고 소비자가 생각할 수 있는데, 이러한 생각이 아이덴티티 입 증 원리이다(Reed et al., 2012). 아이덴티티 입증 원리에 의하 면, 소비자는 특정의 실제적 자아를 어떻게 활성화시키고 표상 하는가를 자신의 환경과 관련하여 평가한다. 그리고 제품이나 브랜드의 사용에 관한 정보에서 자신의 이상적 자아를 제품이 나 브랜드가 표현하게 한다면, 자신의 향상된 자아가 표현될 수 있다고 소비자가 생각할 수 있는데, 이러한 생각이 아이덴 티티 향상 원리이다.

그런데 지각의 자동적인 행동유도효과 이론(Theories on automatic perception-behavior effects)은 행동효과가 목적개념 (goal construct)이나 의미개념(semantic construct)과 같은 심 적 표상(mental representation)기억의 활성화에 의해 매개된다 는 가정에 기초하고 있다. 의미개념은 사회적 상호작용 과정에 서 의미의 대상과 관련하여 활성화되는 추상적 개념인데, 의미 개념과 관련된 행동지식도 기억에서 순간적으로 의미개념을 접근시킬 수 있다. 목적개념과 달리, 의미개념의 활성화 과정 은 수동적이고, 자극에 노출되었을 때 기억에서 활성화된 의미 개념이 관련행동을 연상시켜서 그 행동을 즉시적으로 유도할 가능성을 증가시키지만, 활성화된 의미개념은 시간이 흐르면서 재활성화되지 않으면 기억에서 쇠퇴하고 사라지는 경향이 있다 (Bargh, Gollwitzer, Lee-Chai, Barndollar, \& Trötschel, 2001).

그런데 활성화된 자극의 의미개념이 소비자의 자아개념 요 소와 겹치는 정도가 클수록 자아개념이 부각되어 소비자의 즉 시적 행동에 더 영향을 미칠 수 있어서, 소비자가 추구하는 자 아에 일치하는 의미의 점화는 즉시적인 행동을 유도하는 행동 효과를 유도할 수 있다(Brewer \& Pierce, 2005). 자극의 심적 표상은 기억에서 반복적으로 일관되게 활성화되는 자극의 특 징 또는 행동의 결과와 관련되어 연상되는데, 의미개념이나 목 적개념은 모두 자극에 대한 지각에 의해 기억에서 자동적으로 활성화될 수 있다. 그리고 활성화된 목적이나 의미개념은 특정 행동을 유도할 수 있는데, 점화된 의미개념과 기억에서 활성화 된 자아개념 간의 일치성 지각정도가 자극의 의미의 행동효과에 영향을 미친다(Dijksterhuis, Smith, van Baaren, \& Wigboldus, 2005). 점화된 의미개념이 실제자아개념을 반영할 때 좀 더 즉시적인 의미개념 점화의 행동효과가 발생하고, 점화된 내용 이 실제자아 개념과 격차가 있을 때 좀 더 지속적인 목적의 점화효과가 발생할 수 있다(Sela \& Shiv, 2009).

그런데 자극에 대한 의미점화의 즉시적인 행동효과와 달리, 
자동적인 목적추구 이론은 목적의 수용에 필요한 세 가지 요 소를 강조하고 있다(Custers \& Aarts, 2005). 첫째, 기억에서 목적활성화는 심적으로 표상되는 최종 상태의 활성화와 최종 상태로서 목적을 성취하게 하는 전략행동의 연상을 포함해야 한다. 활성화된 목적과 목적달성의 수단행동의 연상이 목적의 수용에 필요하다. 둘째, 활성화된 최종 상태의 바람직성이 지 각되고, 목적의 달성이 행복, 만족, 또는 안도감의 긍정적인 감정과 함께 연상되어야 목적이 더욱 활성화된다. 기억에서 의 미개념의 활성화는 긍정적인 가치의 연상을 선행요건으로 하 지 않지만, 목적개념의 활성화는 그 목적에 대한 접근신호로 작용하는 긍정적 감정이나 가치가 최종 상태로 표상될 때 목 적개념이 수용될 수 있어서 목적성취감정의 연상이 수단행동 의 구매 또는 소비를 촉진할 수 있다. 서류가방(briefcase) 개 념을 예로 들어 생각해보면, 서류가방이 소비자에게 노출되면, 비즈니스맨의 일반적 특성이나 비즈니스에서 경쟁행동과 같은 의미개념이 활성화되어 어떤 동기적 특성이 없이 즉시적으로 비즈니스맨과 유사한 행동을 유도할 수 있다. 그런데 이 서류 가방은 자신의 실제자아와 격차가 있는 바람직하고 실현가능 한 최종 상태를 연상하게 할 수 있다. 소비자가 지금 이익을 창출하려는 게임에서 노력을 하고 있다면, 이 서류가방이 성과 가 극대화되는 최종 상태가 되고자 하는 목적개념을 연상시켜 서 이익극대화의 목적이 더욱 활성화될 가능성이 있고, 서류가 방에서 목적성취감정을 느낄 때 그 가방의 구매의도가 높아질 수 있다. 셋째, 목적의 수용과 추구의 조건이 자아격차의 평가 에서 유도될 수 있다. 추구하는 목적이 의식적이든 무의식적이 든 실제 상태와 바람직한 최종 상태간의 지각된 격차를 감소 시키려는 열망에서 유도될 수 있다(Kruglanski et al., 2002). 바람직한 최종 상태가 활성화되어 목적으로 수용되면 소비자 는 지속적으로 자신의 실제 상태와 활성화된 최종 상태를 비 교하여 최종 상태로의 진행정도를 평가한다. 그 격차는 목적을 달성하지 못한 소비자에게 목적달성의 동기를 유발하는 시그 널로 작용할 수 있다.

자아 향상성은 자신에 대한 좋은 견해를 유지하려는 욕망에 기초하여 자신을 긍정적이고 좋게 부추기는 정보를 선호하게 하 고 자존감을 촉진하려 한다. 자아 입증성은 자신에 대한 새로운 정보의 학습보다 기존의 자아신념을 입증하려는 욕망에 의해서 자아개념의 일관성을 유지하게 한다(Tice \& Masicampo, 2008). 소비자는 좋은 일을 숙고하여 자신의 삶을 좋게 해석하고 유 지하려는 성향이 있다. 따라서 자아 입증성동기와 자아 향상성 동기는 자신에 대한 좋은 견해를 확인할 수 있는 정보의 선호 관점에서 유사할 수 있다. 즉 소비자는, 자아 입증성 동기와 향상성동기에 관계없이, 정확하지 못하고 불공평하며 기존의 자아 지식에 부합하지 못한 자신에 대한 부정적인 정보에 의 해 모욕을 당하는 것을 싫어하고, 자존감 목적에 초점을 둘수 록 자존감을 충족시키려 할 수 있다.

따라서 브랜드가 소비자의 자질과 유사한 의미개념으로 일 관되게 표출되어 브랜드가 소비자의 자질에 부합하다는 브랜 드의 자아 메시지에서, 자아입증성의 지각은 브랜드가 목적을 성취하게 하는 수단으로 연상되어 브랜드의 선택을 용이하게 할 수 있다. 그리고 자아입증성의 지각은 목적에 대한 접근신 호로 작용하여 목적성취감정을 느끼게 할 수 있다.

H3-1: 자아 입증성이 선택결정용이성에 긍정적인 영향을 미 칠 것이다.

H3-2: 자아 입증성이 목적성취감정에 긍정적인 영향을 미칠
것이다.

바람직한 최종 상태가 기억에서 접근될수록 그 자아격차를 더욱 지각하게 되고 목적이 더욱 활성화되고 추구될 수 있다. 추구하는 목적이 의식적이든 무의식적이든 실제 상태와 바람 직한 최종 상태간의 지각된 격차를 감소시키려는 열망에서 유 도될 수 있다(Kruglanski et al., 2002). 실제자아와 격차가 있 는 바람직하고 실현가능한 최종의 이상적인 자아의 획득을 연 상하게 하는 브랜드의 자아 메시지에서, 자아향상성의 지각은 브랜드가 자아를 향상하는 수단으로 연상되어 브랜드의 선택 을 용이하게 할 수 있고, 자아향상 목적에 대한 접근신호로 작 용하여 목적성취감정을 느끼게 할 수 있다.

H4-1: 자아 향상성이 선택결정용이성에 긍정적인 영향을 미 칠 것이다.

H4-2: 자아 향상성이 목적성취감정에 긍정적인 영향을 미칠 것이다.

\section{3. 자아메시지 유형별 영향을 조절하는 환경감정 프 라이드}

이 연구는 소비자가 제품이나 브랜드 메시지에 노출되었을 때에 메시지의 구매의도 촉진에서 매개변수와 환경적 프라이 드 감정의 조절효과에 관한 연구이다. 감정(affect)은 기분 (mood)과 정서(emotion)를 모두 포함하는 개념이다. 기분은, 좋은 느낌 또는 나쁜 느낌 등과 같이, 뚜렷한 원인변수가 없어 서 기분을 유도하는 내용이 없으며, 상대적으로 강도가 약하고 포괄적이며 지속적인 감정 상태로 정의된다. 그런데 정서은 명 확하고 원형적인 원인을 갖고 있으며 높은 기억 접근성이 있 고 상대적으로 지속성이 낮지만 강한 감정이다. 메시꺼움 (disgust), 화, 공포 등은 정서에 속하는 감정이다. 따라서 기분 은 상대적으로 느낌(feeling)에 기초한 개념이고, 정서는 정서 를 유발하는 원인을 갖고 있고 상대적으로 사고(thought)에 기 초한 감정이다(Forgas, 2001).

그리고 감정은 평가나 판단의 대상에서 느끼는 통합 감정 (integral affect)과 그 대상과 관계없이 사전에 느끼고 대상의 평가나 판단에 영향을 미치는 환경 감정(incidental affect)으로 구분된다. 소비자는 환경감정의 긍정 또는 부정의 방향성뿐만 아니라 환경감정이 환기된 정도 또는 유발요인으로 인지된 요 소를 평가의 대상에 귀인 시켜서, 평가 대상에 대한 반응을 하 고 극단적인 평가를 하게 하는 기능을 한다(Gorn, Pham, \& $\operatorname{Sin}, 2001)$. 또한 감정은 생존과 관련된 공포, 불안 등의 기초 감정과 자아평가와 관련되는 부끄러움, 당황, 프라이드, 죄책감 등의 자아의식 감정으로 나누어진다(Beer \& Keltner, 2004). 이 연구는 감정을 유발하는 원인이 있고 상대적으로 사고에 기초 한 자아의식 감정으로서 환경적 프라이드와 관련된 연구이다.

프라이드는 자아를 중요한 목적의 달성에 귀인 시껴 느끼는 긍정적인 독특한 감정으로, 복잡한 자아규제 또는 통제의 인지 적 평가과정에서 유도된다(Tracy \& Robins, 2004). 자아의 귀 인에서 자신의 자질을 귀인시키면 오만성 프라이드를 느끼고, 자신의 노력을 귀인시키면 진정성 프라이드를 느끼게 된다 (Tracy \& Robins, 2007). 일반적인 자아(global self)가 성공에 귀인되어, 내가 누구인가에서 프라이드를 느끼는(I feel proud of who I am) 경우에 오만성 프라이드를 느끼고, 자신이 행동 한 자아의 구체적인 측면(specific aspects of self)이 성공에 
귀인되어 내가 무엇을 했는가에서 프라이드를 느끼는(I feel proud of what I did) 경우에 진정성 프라이드를 느낀다(Tracy \& Robins, 2014).

일반적인 자아의 귀인에는 주인공인 주체(subject)로서 자아 와 객체(object)로서 자아가 모두 존재하는데, 객체자아와 주체 자아가 얽혀져 전체자아(global self)를 형성한다. 나의 평가에 서 초점이 전체자아에 있으면 오만성 프라이드를 느낀다. 그런 데 구체적인 귀인에서는 전체자아가 아니고 특정의 상황과 시 각에서 구체적인 행동인 구체적인 자아(specific self)가 귀인이 며, 특정 상황, 사람 등과 상호작용한 자신의 행동이 초점을 받게 되어(Lewis, 2016) 진정성 프라이드를 느낀다. 따라서 오 만성 프라이드와 진정성 프라이드로 구분하여 접근할 필요가 있다. 오만성 프라이드는 안정적이고 불변적 자질(traits)에 기 초한 전체자아가 귀인 되는 성공에서 느껴지는 감정이고, 진정 성 프라이드는 안정적이지 못하고 가변적인 노력(efforts)이 귀 인 되는 성공에서 느껴지는 감정이다. 그리고 오만성 프라이드 는 자신의 자질이 위협을 받는 것에서 방어적 자아 존중감과 나 르시시즘에서 나타나는 불안정한 자아가치(unstable self-worth) 와 관련되고, 진정성 프라이드는 안정적인 자존감(stable self-esteem)과 진정성이 반영된 참된 자아가치 및 자아 청렴 성과 관련된다(Tracy, Cheng, Martens, \& Robins, 2011).

따라서 브랜드 메시지에서 총체적인 불변적 기질에 기초하 여 자아의 일관성에 초점을 둔 자아 입증성 소구와 구체적인 자아의 격차에 기초하여 자아상향에 초점을 둔 자아 향상성의 소구가 선택결정용이성과 목적성취감정에 영향을 미치는 정도 는 사전에 느낀 프라이드의 유형에 의해 조절될 것이다.

H5-1: 자아 입증성이 선택결정용이성에 영향을 미치는 정도는 진정성 프라이드보다 오만성 프라이드에서 클 것이다.

H5-2: 자아 입증성이 목적성취감정에 영향을 미치는 정도는 진정성 프라이드보다 오만성 프라이드에서 클 것이다.

H6-1: 자아 향상성이 선택결정용이성에 영향을 미치는 정도는 오만성 프라이드보다 진정성 프라이드에서 클 것이다.

H6-2: 자아 향상성이 목적성취감정에 영향을 미치는 정도는 오만성 프라이드보다 진정성 프라이드에서 클 것이다.

이 연구의 가설들을 요약하여 표현하면 Figure 1과 같다.

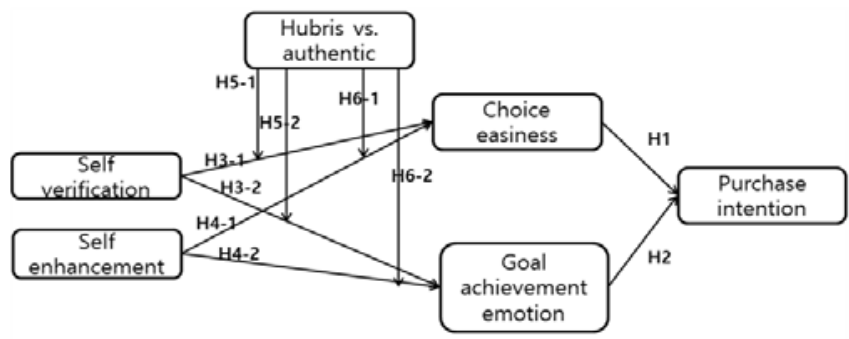

Figure 1: Summary of Research Hypotheses

\section{3. 실증연구 방법}

실증연구는 설문조사로 수행된다. 작성된 설문지를 사전조 사를 통해서 검토수정하고 본 설문이 진행된다. 실증은 2(프라 이드 유형: 진정성 프라이드, 오만성 프라이드) $\times 2$ 2(메시지의
유형: 자아입증 메시지, 자아향상 메시지)의 집단간 설계로 진 핸된다. 그리고 브랜드는 기존의 브랜드를 사용할 경우에 친숙 성효과가 있을 수 있어서 가상의 ' $\mathrm{K}$ ' 브랜드 스마트 폰을 사용 한다. 수집된 자료에 의한 가설의 검증에는 자아메시지의 유형 별로 선택결정용이성과 목적성취감정의 매개역할을 분석하기 위하여, Hayes(2013)의 모형 7이 사용된다.

\section{1. 구성개념의 측정}

\subsection{1. 진정성 프라이드와 오만성 프라이드의 측정}

Ashton-James and Tracy(2012)과 Tracy and Robins(2007) 의 진정성 프라이드를 유도하는 방법을 사용한다. 피험자들에 게 과거에 중요한 목적을 노력하여 달성했던 이벤트를 기억하 게 하고 목적의 달성을 위해서 무엇을 했고(what they did) 또 노력을 한 정도를 기술하게 한다.

이벤트기술에서 관여도를 '관여도' '관심도' ‘몰입정도'에 대 하여 7 점 척도(1=전혀 그렇지 않다, $7=$ 매우 그렇다)로 측정하 고, 목적의 성취에 '(1) 나의 노력에 의한 성취감, 노력에 의한 성공에 프라이드를 느낌 (2) 나의 우수한 자질에 의해 성취감, 내 자신의 자질에 의한 성공에 프라이드를 느낌 (3) 기타'에서 하나를 선택하게 하고, 노력과 자질의 귀인을 식별하는데, (1) 이 아닌 (2)나 (3)을 선택하면 제거하는 응답한 설문지의 필터 문항으로 사용한다.

진정성 프라이드를 느끼는 정도를 Ashton-James and Tracy (2012)의 척도로 측정한다. 즉 '내가 노력해서 목적이 달성되 었다(accomplished)고 느낀다', '내가 노력해서 목적을 성취하 였다(achieving)고 느낀다', '이 이벤트에서 자부심을 느겼다 (confident)', '내가 노력해서 목적이 충족되었다(fulfilled)고 느낀 다', '나의 노력은 생산적이었다(productive)고 느낀다', '이 이벤트 는 나 자신이 가치가 있음을 느끼게 했다(having self-worth)', '내 가 노력한 이 이벤트는 매우 성공적이었다(successful)고 느낀 다'의 문항을 7점 척도로 측정한다.

Ashton-James and Tracy(2012)과 Tracy and Robins(2007) 의 방법을 참고하여, 오만성 프라이드를 느끼게 하기 위해, 첫 째, 그들의 타고난 지능, 자질 등을 기술하게 한다. 그리고 둘 째, 타고난 지능, 자질 등에 의해 중요한 목적을 달성했다고 생각되는 이벤트를 기억하여 서술하게 하고, 셋째, 그 이벤트 에서 목적달성의 중요요인을 기술하게 한다.

기술관여도, 목적의 성취에 귀인 되는 것은 진정성의 경우 와 같다. 오만성 프라이드를 느끼는 정도의 측정척도는 '그 이벤트를 떠올리면, 나는 능력자로 생각된다(conceited),' '그 이벤트에서 내 자신이 대단하게 느껴진다(arrogant),' '이 성공의 중심에는 내가 있었음을 느낀다(egotistical)', '이런 성공은 나니 까 할 수 있다고 느껴진다(pompous),' '그 이벤트를 떠올리면, 나는 다른 사람들에게 나의 재능(능력)을 자랑하고 싶어진다 (smug),' '나는 남들과 품격이 다르다고 느껴진다(snobbish),' '그 이벤트를 떠올리면, 나는 내 자신을 자랑하면서 으스대고 싶다(stuck-up)'의 문항을 7점 척도로 측정한다.

\subsection{2. 자아향상성 및 자아입증성의 메시지와 측정}

소비자의 자아 향상성은 자아의 긍정성을 높이고 부정적인 정보에서 자신을 보호하려는 자아평가적 욕망과 관련되어, 과 업의 자아입증적 진단성보다 과업성과의 방향성에 관심을 두게 하고, 소비자의 성공, 고능력, 긍정적 퍼스널리티를 반영할 수 
있는 과업을 좀 더 매력적으로 생각하게 한다(Swann, 1983; Swann, Chang-Schneider, \& McClarty, 2007). 따라서 자아향 상성 메시지는 열정, 성과, 성공한 사람의 품격 등을 강조하여 개발된다. 그리고 자아향상성의 측정은 타인 또는 평균적인 사 람과 비교하여 자신을 판단하게 하여 측정한다(Suls, Lemos, \& Stewart, 2002)

자아향상성 메시지를 '성공한 사람의 품격을 보여주는 ' $\mathrm{K}$ 스마트폰', 승화노력의 결실 ' $\mathrm{K}$ 스마트폰'과 함께 하는 순간, 당신은 부러움의 대상이 됩니다. 'K 스마트폰’은 당신의 열정 과 성공을 보여줍니다. 언제나 부러움을 받는 당신... 당신이 있는 그 곳에 ‘K 스마트폰’이 있습니다. ‘나의 열정 노력!, 나의 성공!' ‘ $\mathrm{K}$ 스마트폰’으로 개발하고 세 가지의 사진이 부착된 광 고를 작성하였다.

그리고 메시지의 자아향상성의 측정에 '이 브랜드 메시지는 나의 자아를 향상시킬 수 있는 특성을 강조하고 있다' '나는 이 브랜드를 사용하여 타인보다 향상된 나의 모습을 타인에게 보여줄 수 있다' '나는 이 브랜드를 사용하여 타인보다 성공한 나의 모습을 타인에게 보여줄 수 있다' '나는 이 브랜드를 사 용하여 타인보다 우수한 나의 능력을 타인에게 보여줄 수 있 다'의 문항을 이용하여 7점 척도로 측정하였다.

그런데 소비자의 자아 입증성은 기존의 자아개념을 입증하 려는 동기와 관련되어, 기존의 자아개념과 일치하는 피드백 정 보를 찾아서 자신의 자아를 입증하게 한다. 자아개념이나 피드 백 정보의 방향성 보다 기존의 자아개념과 피드백 정보 간의 일관성에 초점을 두게 한다(Swann, 1983; Swann, ChangSchneider, \& McClarty, 2007). 따라서 자아입증성 메시지는 능력, 자질, 자질을 갖춘 사람의 능력 등을 강조하여 개발된다. 자아입증성 메시지를 '사람의 자질과 능력을 보여주는 ' $\mathrm{K}$ 스마 트폰' 뛰어난 능력의 결실 ‘ $\mathrm{K}$ 스마트폰'과 함께 하는 순간, 당 신의 능력이 입증됩니다. ' $\mathrm{K}$ 스마트폰'은 당신의 현재와 능력을 보여줍니다. 언제나 꾸밈없이 당당한 당신... 당신이 있는 그 곳 에 ‘K 스마트폰’이 있습니다. ‘나의 자질!, 나의 능력! ‘ $\mathrm{K}$ 스마트 폰'으로 개발하고 세 가지의 사진이 부착된 광고를 작성하였다.

그리고 메시지의 자아입증성의 측정에 '이 브랜드 메시지는 나의 자아를 입증할 수 있는 특성을 강조 하고 있다' '나는 이 브랜드를 사용하여 나의 실제 모습을 타인에게 보여줄 수 있 다' '나는 이 브랜드를 사용하여 나의 실제 모습을 타인에게 입증할 수 있다' '나의 친구는 이 브랜드를 사용하는 나를 보 고 내가 실제로 누구인가를 알 수 있다'의 문항을 이용하여 7 점 척도로 측정하였다.

\subsection{3. 선택결정 용이성과 목적성취 감정의 측정}

의사결정자의 선택과업의 복잡성 그리고 속성 간의 상쇄 어 려움, 선호 불확실성에 의해서 선택 의사결정에서 어려움이 증 폭될 수 있어서(Anderson, 2003), 선택 의사결정에서 용이성은 선호 확실성, 속성 간의 상쇄 용이성, 그리고 과업의 단순성 등에 의해서 크게 지각될 수 있다. 따라서 선택 의사결정에서 용이성은 '내가 느낀 프라이드 유형관점에서 '나에게 이 브랜 드의 사용에서 자아표현 목적이 명료하다' '나에게 이 브랜드 의 선택결정은 쉬운 문제이다' '나는 이 브랜드의 특징(속성)을 쉽게 파악했다' '를 7점척도로 측정하였다.

소비자는 브랜드를 소비하여 목적을 달성하는 경우에 느껴질 수 있는 감정을 선택하는 브랜드에서 느낄 수 있다(Fishbach, Shah, \& Kruglanski, 2004). 예쁜 드레스에 노출되면 그 드레
스를 착용한 모습이 상상되어 예쁜 자신을 표현하려는 목적이 활성화되고 자신이 선택한 브랜드를 사용하여 목적을 달성하 는 경우에 느낄 수 있는 감정을 느낄 수 있다. 따라서 피험자 에게 자신이 선택한 브랜드를 사용하여 브랜드의 사용목적을 달성하면 느낄 수 있는 감정을 주관적으로 서술하게 한다(귀하 가 이 브랜드를 사용하여 사용목적을 달성하면 느껴질 수 있는 감정을 서술하여 주세요). 그리고 브랜드를 사용하여 목적을 달성하면 느껴지는 목적감정을, '내가 느낀 프라이드 유형관점 에서 나는 이 브랜드를 사용하여 목적을 달성하는 경우에 브랜 드에서 느낄 수 있는 감정을(이) '느낀다' '떠오른다' '연상된다' '기억에서 함께 한다' '를 이용하여 7점 척도로 측정하였다.

\subsection{4. 구매의도의 측정}

Bower(2001)의 척도를 참고하여, '나는 이 브랜드의 구매를 원한다' '나는 이 브랜드를 구매하고 싶다' '나는 이 브랜드의 구매에 관심이 많다' '나는 이 브랜드를 구매할 것이다' '나는 이 브랜드를 구매할 가능성이 많다'를 7점 척도를 사용하여 구 매의도를 측정한다.

\section{4. 실증분석}

\section{1. 자료의 수집과 기초분석}

\subsection{1. 사전 조사와 본 자료의 수집}

사전조사에 설계의 집단별로 5 명씩, 20 명의 학부생을 배정 하여 설문지의 오타, 문장 등을 점검하여 수정하고, 본 설문지 를 완성하였다. 본 조사에서 설계의 집단별로 마케팅관련과목 을 수강하는 학부생을 55 명씩 배정하고, 설문지를 배포하였다. 사전에 집단별로 문화상품권이 설문조사 후에 추첨으로 배부 됨을 고지하고, 문화상품권을 설문 후에 추첨하여 증정하였다. 설문지를 회수하고, 면밀히 검토하였다. 오만성 프라이드 집단 에서 주로 달리기, 노래 경쟁, 손 놀이 등이 피험자들이 기억 한 이벤트였는데, 목적의 성취에 노력과 자질이 작용한 정도의 귀인식별 설문에서 (1)이 아닌 (2)나 (3)을 선택한 3명의 피험자 를 제외하였다. 진정성 프라이드 집단에서 피험자들이 주로 공 모전 입상, 그림그리기, 쪽지시험 등이 기억한 이벤트인데, 귀 인식별 설문에서 (2)가 아닌 (1)이나 (3)을 선택한 2명의 피험자 를 제외하였다. 2(프라이드 유형: 진정성 프라이드, 오만성 프 라이드) $\times 2$ (메시지의 유형: 자아입증 메시지, 자아향상 메시 지)의 집단 간 실험설계에서 각 실험집단에서 학부생 55 명씩, 220 명에게 설문지를 배포하고, 응답에 오류가 있는 5 명의 설 문지를 제외하고, 215 부의 자료가 최종 자료이다. 오만성 프라 이드-자아입증 메시지 집단에서 54부, 오만성 프라이드-자아향 상 메시지 집단에서 53부, 진정성 프라이드-자아입증 메시지 집단에서 53 부, 진정성 프라이드-자아향상 메시지 집단에서 55 부 의 자료가 이용되는데, 자아입증 메시지 집단의 107 부 자료, 그 리고 자아향상 메시지 집단에서 108부의 자료에 의해 Macro process 7 의 모형으로 가설을 검증하는 실증분석을 하였다.

\subsection{2. 기초분석}

응답자는 남자(128명) 여자(87명)이며, 오만성 집단(107명) 진정성 집단(108명)이며, 모두 대학생 이었다. 그리고 Table 1 
에 제시한 바와 같이, 느낀 프라이드의 서술응답에서 주의한 정도 $(\alpha=.885)$ 가 실헙집단 간에 차이가 없음을 식별하였다 $(\mathrm{t}=.273, \mathrm{p}>.05)$. 그리고 오만성 프라이드 집단에서 오만성 프 라이드 $(\alpha=.918)$ 를 느낀 정도 $(\mathrm{M}=4.2870)$ 가 4 보다 크게 나타났 고 $(\mathrm{t}=2.2179, \mathrm{p}<.05)$, 진정성 프라이드 집단에서 진정성 프라이 드 $(\alpha=.925)$ 를 느낀 정도 $(\mathrm{M}=5.7262)$ 가 4보다 크게 나타나 $(\mathrm{t}=19.024, \mathrm{p}<.01)$, 프라이드 유형의 실험조작이 의미가 있음을 식별하였다.

Table 1: Characteristics of Sample at Each Pride Group

\begin{tabular}{|c|c|c|l|}
\hline & Hubris $(\mathbf{N}=107)$ & Authentic $(\mathbf{N}=108)$ & \\
\hline Attention & $M=5.5078$ & $M=5.4660$, & \multirow{2}{*}{$\mathrm{t}=.273, \mathrm{p}>.05$} \\
degree & $\mathrm{S} . \mathrm{D}=1.11625$ & $\mathrm{~S} . \mathrm{D}=1.12550$ & \\
\hline \multirow{2}{*}{ Pride-feeling } & $\mathrm{M}=4.2870>4$ & $\mathrm{M}=5.7262>4$ & \\
degree & $\mathrm{S} . \mathrm{D}=1.36298$ & $\mathrm{~S} . \mathrm{D}=.9429$ & \\
& $(\mathrm{t}=2.2179, \mathrm{p}<.05)$ & $(\mathrm{t}=19.024, \mathrm{p}<.01)$ & \\
\hline
\end{tabular}

이 연구에서 사용한 메시지유형의 집단별로, 즉 자아향상과 입증의 메시지 집단별로 구성개념들의 측정항목에 대하여 확 인적 주성분 요인분석을 하였는데, 선택용이성의 측정 항목에 서 첫 번째 문항과 구매의도의 측정에서 네 번째 문항이 각 구성개념에 수렴되지 않아서 제외하였고, 자아향상 메시지 집 단의 결과는 Table 3 과 같고, 자아입증의 메시지 집단의 결과 는 Table 4와 같다. 각 집단에서 구성개념들의 측정문항들이 모 두 관련 개념에 수렴하였고, 또 신뢰도(reliability) (Cronbach's $\alpha)$ 도 모두 .700 이상으로 식별되었다. Table 5 및 6 과 같이, Amos 21.0의 구조방정식 모형에 의해 도출된 구성개념들 간 의 상관계수의 제곱값이 AVE보다 작고, 또 각 AVE의 값이 모 두 .5이상이 되어 구성개념들 간의 판별 타당성이 식별되었 다, 각 구성개념별로 측정항목의 점수를 합산하고 평균하여 분 석에 이용하였다. 본 연구에서 실증을 위해 사용된 변수의 측 정항목의 수를 조작적 정의와 함께 정리하면 Table 2과 같다.

Table 2: Operational Definition of Variables

\begin{tabular}{|c|c|c|c|}
\hline Classification & Operational Definition & \# of items & References \\
\hline $\begin{array}{l}\text { Purchase } \\
\text { intention }\end{array}$ & $\begin{array}{c}\text { Individual's conscious plan to make an effort to } \\
\text { purchase a brand }\end{array}$ & - & $\begin{array}{c}\text { Bower (2001), } \\
\text { Spears and Singh (2004). }\end{array}$ \\
\hline $\begin{array}{l}\text { Goal achievement } \\
\text { emotion }\end{array}$ & Prediction of how consumers will feel in achieving goal & 4 & $\begin{array}{l}\text { Fishbach, Shah, and Kruglanski (2004), } \\
\text { Hoyer, Maclnnis, and Pieters (2018) }\end{array}$ \\
\hline $\begin{array}{c}\text { Self } \\
\text { Enhancement }\end{array}$ & $\begin{array}{l}\text { The extent to which consumers hold an excessively } \\
\text { flattering view of themselves and of things associated } \\
\text { with the self }\end{array}$ & 4 & $\begin{array}{l}\text { Suls, Lemos, and Stewart (2002), } \\
\text { Sedikides and Greg (2008) }\end{array}$ \\
\hline $\begin{array}{c}\text { Self } \\
\text { Verification }\end{array}$ & $\begin{array}{l}\text { The extent to which feedback from the external } \\
\text { environment will be introspectively processed to } \\
\text { determine progress toward the actual representation of } \\
\text { an identity }\end{array}$ & 4 & $\begin{array}{l}\text { Swann, Chang-Schneider, and } \\
\text { McClarty (2007), Reed, Forehand, } \\
\text { Puntoni, and Warlop (2012) }\end{array}$ \\
\hline $\begin{array}{l}\text { Choice } \\
\text { easiness }\end{array}$ & $\begin{array}{c}\text { Easiness felt when consumers elect to choose from } \\
\text { large assortment or increase size of self-generated } \\
\text { option set }\end{array}$ & 2 & Anderson (2003) \\
\hline
\end{tabular}

Table 3: Results of Analyzing Principal Components at Self-Enhancing Message

\begin{tabular}{|c|c|c|c|c|c|c|c|}
\hline \multirow{2}{*}{ Construct } & \multirow{2}{*}{ Items } & \multicolumn{4}{|c|}{ Component } & \multirow{2}{*}{$\alpha$} & \multirow{2}{*}{ Mean and S.D } \\
\hline & & 1 & 2 & 3 & 4 & & \\
\hline \multirow{4}{*}{$\begin{array}{l}\text { Purchase } \\
\text { intention }\end{array}$} & Pintent5 & .870 & .229 & .198 & .201 & \multirow{4}{*}{.963} & \multirow{4}{*}{$\begin{array}{c}M=3.1449, \\
S . D=1.44475\end{array}$} \\
\hline & Pintent2 & .863 & .283 & .268 & .106 & & \\
\hline & Pintent1 & .856 & .250 & .281 & .115 & & \\
\hline & Pintent3 & .845 & .302 & .280 & .184 & & \\
\hline \multirow{4}{*}{$\begin{array}{c}\text { Goal achievement } \\
\text { emotion }\end{array}$} & Gemot2 & .275 & .875 & .202 & .193 & \multirow{4}{*}{.944} & \multirow{4}{*}{$\begin{array}{c}M=3.9182, \\
S . D=1.26621\end{array}$} \\
\hline & Gemot1 & .205 & .868 & .226 & .167 & & \\
\hline & Gemot3 & .270 & .836 & .215 & .207 & & \\
\hline & Gemot4 & .406 & .694 & .281 & .292 & & \\
\hline \multirow{4}{*}{$\begin{array}{c}\text { Self } \\
\text { Enhancement }\end{array}$} & Sdegree2 & .243 & .245 & .872 & .032 & \multirow{4}{*}{.885} & \multirow{4}{*}{$\begin{array}{c}M=4.0631, \\
S . D=1.47826\end{array}$} \\
\hline & Sdegree3 & .309 & .332 & .808 & .018 & & \\
\hline & Sdegree1 & .137 & .098 & .714 & .230 & & \\
\hline & Sdegree4 & .523 & .218 & .673 & .082 & & \\
\hline \multirow{2}{*}{$\begin{array}{l}\text { Choice } \\
\text { easiness }\end{array}$} & Ceasy3 & .136 & .265 & .042 & .877 & \multirow{2}{*}{.700} & \multirow{2}{*}{$\begin{array}{c}M=3.8505, \\
S . D=1.28345\end{array}$} \\
\hline & Ceasy2 & .332 & .335 & .341 & .626 & & \\
\hline \multicolumn{2}{|c|}{ eigen value } & 3.880 & 3.396 & 2.979 & 1.515 & & \\
\hline \multicolumn{2}{|c|}{$\%$ variance } & 27.715 & 24.255 & 21.276 & 10.821 & & \\
\hline
\end{tabular}


Table 4: Results of Analyzing Principal Components at Self-Verifying Message

\begin{tabular}{|c|c|c|c|c|c|c|c|}
\hline \multirow{2}{*}{ Construct } & \multirow{2}{*}{ Item } & \multicolumn{3}{|c|}{ Component } & \multirow[b]{2}{*}{4} & \multirow{2}{*}{$\alpha$} & \multirow{2}{*}{ Mean and S.D } \\
\hline & & 1 & 2 & 3 & & & \\
\hline \multirow{4}{*}{$\begin{array}{l}\text { Purchase } \\
\text { intention }\end{array}$} & Pintent3 & .886 & .264 & .251 & .200 & \multirow{4}{*}{.975} & \multirow{4}{*}{$\begin{array}{c}M=3.7755 \\
S . D=1.69591\end{array}$} \\
\hline & Pintent5 & .882 & .292 & .157 & .102 & & \\
\hline & Pintent2 & .854 & .256 & .253 & .276 & & \\
\hline & Pintent1 & .839 & .292 & .283 & .261 & & \\
\hline \multirow{4}{*}{$\begin{array}{c}\text { Goal achievement } \\
\text { emotion }\end{array}$} & Gemot3 & .305 & .845 & .246 & .156 & \multirow{4}{*}{.954} & \multirow{4}{*}{$\begin{array}{c}M=4.4861 \\
S . D=1.30591\end{array}$} \\
\hline & Gemot2 & .339 & .838 & .244 & .106 & & \\
\hline & Gemot4 & .349 & .764 & .391 & .225 & & \\
\hline & Gemot1 & .231 & .760 & .331 & .323 & & \\
\hline \multirow{4}{*}{$\begin{array}{c}\text { Self } \\
\text { Verification }\end{array}$} & Sdegree3 & .258 & .229 & .816 & .314 & \multirow{4}{*}{.883} & \multirow{4}{*}{$\begin{array}{c}M=4.3738 \\
S . D=1.31589\end{array}$} \\
\hline & Sdegree2 & .279 & .245 & .797 & .097 & & \\
\hline & Sdegree4 & .441 & .187 & .729 & .169 & & \\
\hline & Sdegree1 & .010 & .421 & .693 & .062 & & \\
\hline \multirow{2}{*}{$\begin{array}{c}\text { Choice } \\
\text { easiness }\end{array}$} & Ceasy3 & .378 & .257 & .174 & .797 & \multirow{2}{*}{.775} & \multirow{2}{*}{$\begin{array}{c}M=4.4491 \\
S . D=1.25106\end{array}$} \\
\hline & Ceasy2 & .276 & .350 & .511 & .588 & & \\
\hline \multicolumn{2}{|c|}{ eigen value } & 3.938 & 3.398 & 3.218 & 1.505 & & \\
\hline \multicolumn{2}{|c|}{$\%$ variance } & 28.131 & 24.271 & 22.989 & 10.749 & & \\
\hline
\end{tabular}

Table 5: Correlations among Constructs at Self-Enhancing Message

\begin{tabular}{|c|c|c|c|c|}
\hline & Purchase intention & Goal achievement emotion & Self verification & Choice easiness \\
\hline Purchase intention & .927 & & & \\
\hline Goal achievement emotion & $\begin{array}{c}.695 \\
(.483) \\
\end{array}$ & .835 & & \\
\hline Self verification & $\begin{array}{c}.661 \\
(.437) \\
\end{array}$ & $\begin{array}{c}.743 \\
(.552) \\
\end{array}$ & .677 & \\
\hline Choice easiness & $\begin{array}{c}.709 \\
(.503)\end{array}$ & $\begin{array}{c}.746 \\
(.557)\end{array}$ & $\begin{array}{c}.796 \\
(.634)\end{array}$ & .650 \\
\hline
\end{tabular}

Note: The figures on diagonal line mean AVE, and the figures in $(\quad)$ are the squares of correlation coefficients.

Table 6: Correlations among Constructs at Self-Verifying Message

\begin{tabular}{|c|c|c|c|c|}
\hline & Purchase intention & Goal achievement emotion & Self enhancement & Choice easiness \\
\hline Purchase intention & .868 & & & \\
\hline Goal achievement emotion & $\begin{array}{c}650 \\
(.423) \\
\end{array}$ & .803 & & \\
\hline Self enhancement & $\begin{array}{c}.649 \\
(.421) \\
\end{array}$ & $\begin{array}{c}.595 \\
(.354) \\
\end{array}$ & .604 & \\
\hline Choice easiness & $\begin{array}{c}.652 \\
(.425) \\
\end{array}$ & $\begin{array}{c}.717 \\
(.514) \\
\end{array}$ & $\begin{array}{c}.573 \\
(.328) \\
\end{array}$ & .576 \\
\hline
\end{tabular}

Note: The figures on diagonal line mean AVE, and the figures in $(\quad)$ are the squares of correlation coefficients.

\section{2. 가설의 검증}

Macro process model 7 (Hayes, 2013) 을 이용하여 각 메 시지 집단별로 자료를 통합하고 가설을 검증하였다. 프라이드 의 유형 집단은 오만성 프라이드 집단(0)과 진정성 프라이드 집단(1)으로 더미처리 하였다.

\subsection{1. 자아입증성 메시지 집단에서 가설검증}

4.2.1.1. 자아입증성의 선택용이성 효과와 프라이드 유형 의 조절작용 가설의 검증

Table 7에서 보는 바와 같이, 선택용이성의 구매의도 효과 (H1)가 회귀계수(coeff=.6736) $(\mathrm{t}=5.1787, \mathrm{p}<.01)$ 로 채택되었다.
자아입증성 메시지 집단에서 선택용이성에 자아입증성의 효과 (H3-1)는 회귀계수(coeff=.9277) $(\mathrm{t}=9.4254, \mathrm{p}<.01)$ 로 채택되었 고, 프라이드 유형의 조절작용(H5-1)도 회귀계수(coeff=-.5617) $(\mathrm{t}=-4.2397, \mathrm{p}<.01)$ 로 채택되었다. 따라서 자아입증성 메시지 집단에서 자아입증성의 지각정도가 선택결정용이성에 미치는 영향은 진정성 프라이드보다 오만성 프라이드 집단에서 더 크 며, 브랜드의 구매의도에 선택결정용이성이 긍정적인 영향을 미치는 것으로 탐색되었다.

4.2.1.2. 목적성취감정의 매개역할과 프라이드 유형의 조 절작용 가설의 검증

Table 8에서 보는 바와 같이, 자아입증성 메시지 집단에서 목적성취감정의 구매의도 효과(H2)가 회귀계수(coeff=.6003) 
Table 7: Moderation Role of Pride Type in the Effects of Self Verification on Choice Easiness at Self-Verifying Message

\begin{tabular}{|c|c|c|c|c|c|c|c|c|}
\hline \multicolumn{9}{|c|}{ Outcome : choice easiness } \\
\hline \multicolumn{9}{|c|}{ Model Summary } \\
\hline & $\mathbf{R}$ & R-sq & MSE & $F$ & Df1 & Df2 & & $\mathbf{P}$ \\
\hline & .7457 & .5561 & .7035 & 43.0034 & 3 & 103 & & 0000 \\
\hline \multicolumn{9}{|c|}{ Model } \\
\hline & coeff & se & $t$ & $p$ & $\mathrm{LLCl}$ & ULCI & $\mathrm{H}$ & Results \\
\hline Constant & .3477 & .4867 & .7144 & .4766 & -.6175 & 1.3129 & & \\
\hline self verification(C) & .9277 & .0984 & 9.4254 & .0000 & .7325 & 1.1229 & H3-1 & accepted \\
\hline pride type(D) & 2.2487 & .6089 & 3.6930 & .0004 & 1.0411 & 3.4564 & & \\
\hline$C \times D$ & -.5617 & .1325 & -4.2398 & .0000 & -.8244 & -.2989 & H5-1 & accepted \\
\hline
\end{tabular}

\begin{tabular}{|c|c|c|c|c|c|c|c|c|}
\hline \multicolumn{9}{|c|}{ Outcome : purchase intention } \\
\hline \multicolumn{9}{|c|}{ Model Summary } \\
\hline & $\mathbf{R}$ & R-sq & MSE & $\mathbf{F}$ & Df1 & Df2 & \multicolumn{2}{|c|}{$\mathbf{P}$} \\
\hline & .7080 & .5012 & 1.4607 & 52.2515 & 2 & 104 & \multicolumn{2}{|c|}{.0000} \\
\hline \multicolumn{9}{|c|}{ Model } \\
\hline & coeff & se & $t$ & $p$ & LLCl & ULCl & $\mathrm{H}$ & Results \\
\hline Constant & -.7240 & .4573 & -1.5832 & .1164 & -1.6309 & .1829 & & \\
\hline choice easiness & .6736 & .1301 & 5.1787 & .0000 & .4157 & .9316 & $\mathrm{H} 1$ & accepted \\
\hline self verification & .3502 & .1227 & 2.8553 & .0052 & .1070 & .5935 & & \\
\hline
\end{tabular}

Table 8: Moderation Role of Pride Type in the Effects of Self Verification on Goal Achievement Emotion at Self-Verifying Message

\begin{tabular}{|c|c|c|c|c|c|c|c|c|}
\hline \multicolumn{9}{|c|}{ Outcome : goal achievement emotion } \\
\hline \multicolumn{9}{|c|}{ Model Summary } \\
\hline & $\mathbf{R}$ & R-sq & MSE & $\mathbf{F}$ & Df1 & Df2 & & $\mathbf{P}$ \\
\hline & .7265 & .5278 & .8080 & 38.3753 & 3 & 103 & & 0000 \\
\hline \multicolumn{9}{|c|}{ Model } \\
\hline & coeff & se & $\mathbf{t}$ & $p$ & LLCl & ULCI & $\mathrm{H}$ & Results \\
\hline Constant & 1.0101 & .5215 & 1.9367 & .0555 & -.0243 & 2.0445 & & \\
\hline self verification(C) & .8268 & .1055 & 7.8387 & .0000 & .6176 & 1.0360 & H3-2 & accepted \\
\hline pride type(D) & 1.2581 & .6526 & 1.9280 & .0566 & -.0361 & 2.5523 & & \\
\hline $\mathrm{C} \times \mathrm{D}$ & -.3831 & .1420 & -2.6983 & .0081 & -.6646 & -.1015 & H5-2 & accepted \\
\hline
\end{tabular}

\begin{tabular}{|c|c|c|c|c|c|c|c|c|}
\hline \multicolumn{9}{|c|}{ Outcome : purchase intention } \\
\hline \multicolumn{9}{|c|}{ Model Summary } \\
\hline & $\mathbf{R}$ & R-sq & MSE & $\mathbf{F}$ & Df1 & Df2 & & $\mathbf{P}$ \\
\hline & .6951 & .4832 & 1.5135 & 48.6135 & 2 & 104 & & .0000 \\
\hline \multicolumn{9}{|c|}{ Model } \\
\hline & coeff & se & $\mathbf{t}$ & $\mathbf{p}$ & LLCI & ULCl & $\mathrm{H}$ & Results \\
\hline Constant & -.5908 & .4603 & -1.2833 & .2022 & -1.5037 & .3221 & & \\
\hline goal achievement emotion & .6003 & .1272 & 4.7174 & .0000 & .3479 & .8526 & $\mathrm{H} 2$ & accepted \\
\hline self verification & .3832 & .1247 & 3.0733 & .0027 & .1359 & .6305 & & \\
\hline
\end{tabular}

$(\mathrm{t}=4.7174, \mathrm{p}<.01)$ 로 채택되었다. 목적성취감정에 자아입증성의 효과(H3-2)는 회귀계수(coeff=.8268) (t=7.8387, $\mathrm{p}<$.01)로 채택 되었고, 프라이드 유형의 조절작용(H5-2)도 회귀계수(coeff= -.3831) ( $\mathrm{t}=-2.6983, \mathrm{p}<.01)$ 로 채택되었다. 따라서 자아입증성 메시지 집단에서 자아입증성의 지각정도가 목적성취감정에 미 치는 영향은 오만성 프라이드에서 진전성 프라이드 보다 더 크며, 브랜드의 구매의도에 목적성취감정이 긍정적인 영향을 미치는 것으로 탐색되었다.

\subsection{2. 자아향상성 메시지 집단에서 가설검증}

4.2.2.1. 자아향상성의 선택용이성 효과와 프라이드 유형 의 조절작용 가설의 검증

Table 9 에서 보는 바와 같이, 선택용이성의 구매의도 효과
(H1)가 회귀계수(coeff=.3264) $(\mathrm{t}=3.6618, \mathrm{p}<.01)$ 로 채택되었다. 자아향상성 메시지 집단에서 선택용이성에 자아향상성의 효과 (H4-1)는 회귀계수(coeff=.3414) $(\mathrm{t}=3.3449, \mathrm{p}<.01)$ 로 채택되었 고, 프라이드 유형의 조절작용(H6-1)은 회귀계수(coeff=.1258) $(\mathrm{t}=.8231, \mathrm{p}>.05)$ 로 기각되었다. 따라서 자아향상성 메시지 집 단에서 자아향상성의 지각정도가 선택용이성에 긍정적인 영향 을 미치지만, 오만성 프라이드와 진전성 프라이드 간의 조절효 과는 없고, 브랜드의 구매의도에 선택용이성이 긍정적인 영향 을 미치는 것으로 탐색되었다.

4.2.2.2. 목적성취감정의 매개역할과 프라이드 유형의 조 절작용

Table 10 에서 보는 바와 같이, 목적성취감정의 구매의도 효 
과(H2)가 회귀계수(coeff=.4337) $(\mathrm{t}=4.6204, \mathrm{p}<.01)$ 로 채택되었 다. 자아향상성 메시지 집단에서 목적성취감정에 자아향상성의 효과(H4-2)는 회귀계수(coeff=.3584) $(\mathrm{t}=4.0111, \mathrm{p}<$.01)로 채택 되었고, 프라이드 유형의 조절작용(H6-2)은 회귀계수(coeff= .3705) $(\mathrm{t}=2.7688, \mathrm{p}<.01)$ 로 채택되었다. 따라서 자아향상성 메
시지 집단에서 자아향상성의 지각정도가 목적성취감정에 미치 는 영향은 오만성 프라이드 보다 진전성 프라이드에서 더 크 며, 브랜드의 구매의도에 목적성취감정이 긍정적인 영향을 미 치는 것으로 탐색되었다.

Table 9: Moderation Role of Pride Type in the Effects of Self Verification on Choice Easiness at Self-Enhancing Message

\begin{tabular}{|c|c|c|c|c|c|c|c|c|}
\hline \multicolumn{9}{|c|}{ Outcome: choice easiness } \\
\hline \multicolumn{9}{|c|}{ Model Summary } \\
\hline & $\mathbf{R}$ & R-sq & MSE & $F$ & Df1 & Df2 & \multicolumn{2}{|c|}{$\mathbf{P}$} \\
\hline & .4632 & .2145 & 1.3316 & 9.3761 & 3 & 103 & \multicolumn{2}{|c|}{.0000} \\
\hline \multicolumn{9}{|c|}{ Model } \\
\hline & coeff & se & $t$ & p & LLCl & ULCI & $\mathrm{H}$ & Results \\
\hline Constant & 2.4647 & .4349 & 5.6675 & .0000 & 1.6022 & 3.3272 & & \\
\hline self enhancement(A) & .3414 & - 1021 & 3.3449 & .0011 & .1390 & .5439 & $\mathrm{H} 4-1$ & accepted \\
\hline pride type(B) & -.5263 & .6614 & -.7958 & .4280 & -1.838 & .7853 & & \\
\hline$A \times B$ & .1258 & .1529 & .8231 & .4123 & -.1774 & .4291 & $\mathrm{H} 6-1$ & rejected \\
\hline
\end{tabular}

\begin{tabular}{|c|c|c|c|c|c|c|c|c|}
\hline \multicolumn{9}{|c|}{ Outcome: purchase intention } \\
\hline \multicolumn{9}{|c|}{ Model Summary } \\
\hline & $\mathbf{R}$ & R-sq & MSE & $\mathbf{F}$ & Df1 & Df2 & & $\mathbf{P}$ \\
\hline & .6959 & .4843 & 1.0971 & 48.8366 & 2 & 104 & & .0000 \\
\hline \multicolumn{9}{|c|}{ Model } \\
\hline & coeff & se & $t$ & p & $\mathrm{LLCl}$ & ULCl & $\mathrm{H}$ & Results \\
\hline Constant & -.1520 & .3580 & -.4246 & .6720 & -.8620 & .5580 & & \\
\hline choice easiness & .3264 & .0891 & 3.661 & .0004 & .1497 & .5032 & $\mathrm{H} 1$ & accepted \\
\hline self enhancement & .5021 & .0774 & 6.487 & .0000 & .3486 & .6556 & & \\
\hline
\end{tabular}

Table 10: Moderation Role of Pride Type in the Effects of Self Enhancement on Goal Achievement Emotion at Self-Enhancing Message

\begin{tabular}{|c|c|c|c|c|c|c|c|c|}
\hline \multicolumn{9}{|c|}{ Outcome: goal achievement emotion } \\
\hline \multicolumn{9}{|c|}{ Model Summary } \\
\hline & $\mathbf{R}$ & R-sq & MSE & $\mathbf{F}$ & Df1 & Df2 & & \\
\hline & .6402 & .4099 & 1.0203 & 23.8503 & 3 & 103 & & 00 \\
\hline \multicolumn{9}{|c|}{ Model } \\
\hline & coeff & se & $t$ & $\mathbf{p}$ & LLCl & ULCI & $\mathrm{H}$ & Results \\
\hline Constant & 2.6379 & .3807 & 6.9294 & .0000 & 1.8829 & 3.3929 & & \\
\hline self enhancement(A) & .3584 & .0894 & 4.0111 & .0001 & .1812 & .5356 & $\mathrm{H} 4-2$ & accepted \\
\hline pride type(B) & -1.8832 & .5789 & -3.253 & .0015 & -3.301 & -.7351 & & \\
\hline$A \times B$ & .3705 & .1338 & 2.7688 & .0067 & .1051 & .6360 & $\mathrm{H} 6-2$ & accepted \\
\hline
\end{tabular}

\begin{tabular}{|c|c|c|c|c|c|c|c|c|}
\hline \multicolumn{9}{|c|}{ Outcome: purchase intention } \\
\hline \multicolumn{9}{|c|}{ Model Summary } \\
\hline & $\mathbf{R}$ & R-sq & MSE & $F$ & Df1 & Df2 & & $\mathbf{P}$ \\
\hline & .7190 & .5170 & 1.0276 & 55.655 & 2 & 104 & & .0000 \\
\hline \multicolumn{9}{|c|}{ Model } \\
\hline & coeff & se & $\mathbf{t}$ & $\mathbf{p}$ & $\mathrm{LLCl}$ & ULCl & $\mathrm{H}$ & Results \\
\hline Constant & -.2136 & .3350 & -.6378 & .5250 & -.8779 & .4506 & & \\
\hline $\begin{array}{c}\text { goal achievement } \\
\text { emotion }\end{array}$ & .4337 & .0939 & 4.6204 & .0000 & .2475 & .6198 & $\mathrm{H} 2$ & accepted \\
\hline self enhancement & .4084 & .0823 & 4.9623 & .0000 & .2452 & .5716 & & \\
\hline
\end{tabular}




\section{5. 결론}

\section{1. 연구의 요약}

이 연구는 기존의 연구에서 자아의 입증메시지와 자아의 향 상메시지에서 서로 다른 소비자의 설득효과에 주의 하지 못하 였고, 어떤 자아 메시지 유형이 사전에 느끼는 프라이드의 유 형이 서로 다른 소비자를 더 설득할 수 있는가에 대한 연구가 부족함을 간파하였다. 따라서 브랜드의 자아의 입증성 메시지 에서 자아입증성의 지각과 자아의 향상성 메시지에서 자아향 상성의 지각이 소비자의 브랜드의 선택결정용이성과 소비목적 의 성취감정에 영향을 미치는 정도를 식별하였고, 구매의도에 선택결정용이성과 목적성취감정의 영향을 탐색하였다. 그리고 자아 메시지에서 지각되는 자아입증성과 자아향상성의 선택결 정용이성과 목적의 성취감정에 대한 영향에 사전에 느낀 프라 이드의 유형이 조절효과를 탐색하였다.

사전에 느낀 프라이드의 유형이 서로 다른 의사결정의 맥락 에서 자아입증성 지각과 자아향상성 지각의 선택결정용이성과 목적의 성취감정에 대한 영향을 이론적으로 검토하고, 선택결 정용이성과 목적의 성취감정의 브랜드 구매의도 효과를 이론 적으로 식별하여 가설을 설정하였다. 그리고 스마트 폰을 실증 제품으로 선정하고 2(프라이드 유형: 진정성 프라이드, 오만성 프라이드) $\times 2$ (메시지의 유형: 자아입증 메시지, 자아향상 메 시지)의 집단 간 실험설계를 하여 각 실험집단에서 학부생 55 명씩, 220명에게 설문지를 배포하고, 응답에 오류가 있는 5명 의 설문지를 제외하고, 215부의 자료에서 자아입증 메시지 집 단의 107 부 자료, 그리고 자아향상 메시지 집단에서 108 부의 자료에 의해 Macro process 7 의 모형으로 가설을 검증하는 실증분석을 하였다. 분석결과는 다음과 같다.

첫째, 브랜드의 구매의도에 선택결정용이성과 목적성취감정 이 긍정적인 영향을 미친다. 둘째, 브랜드 메시지에서 자아입 증성 지각과 자아향상성 지각이 선택결정용이성과 목적의 성 취감정에 긍정적인 영향을 미친다. 셋째, 자아입증 메시지에서 지각되는 자아입증성의 선택결정용이성 효과와 목적의 성취감 정 효과에 사전에 느낀 오만성 프라이드가 진정성 프라이드 보다 더 큰 영향을 미침이 식별되어, 사전에 느낀 프라이드의 유형의 조절효과가 있다. 넷째, 자아향상 메시지에서 지각되는 자아 향상성의 선택결정용이성 효과와 목적의 성취감정 효과 에서 사전에 느낀 진정성 프라이드가 오만성 프라이드 보다 목적의 성취감정을 느끼는 정도에 더 큰 영향을 미치지만, 선 택결정 용이성 정도에 사전에 느낀 프라이드의 유형의 조절효 과가 없었다.

자아향상 메시지에서 지각되는 자아 향상성이 선택결정 용 이성 정도에 미치는 영향이 사전에 느낀 프라이드의 유형, 즉 진정성 프라이드와 오만성 프라이드 간에 조절효과가 없는 것 은 감정인 진정성 프라이드와 인지적 성격이 강한 자아 향상 성 간에 상호작용이 미흡함을 의미할 수 있어서, 프라이드 유 형과 자아 향상성, 각각의 선택결정 용이성의 효과를 병렬적 관점에서 재검토할 필요가 있다.

\section{2. 연구의 시사점과 한계}

\subsection{1. 연구의 시사점}

기존의 연구가, 브랜드의 자아 일치성에 초점을 두고, 브랜
드 선호도와 만족도 효과, 브랜드 태도 효과(Hosany and Martin, 2012; Marshall, Na, State \& Deuskar, 2008), 구매의 도, 충성도(He \& Mukherjee, 2007; Jamal \& Al-Marri, 2007; Mazodier \& Merunka, 2012; Usakli \& Baloglu, 2011)의 예측 효과를 탐색하였다. 또 소비자의 장기목적에 주의하여 쾌락적 소비에서 자아규제(Fishbach, Friedman, \& Kruglanski, 2003), 장기목적의 활성화로 자아통제가 탐닉 제품보다 실용재의 선 택효과(Choi, 2016) 등을 식별하였다. 이 연구는 브랜드의 자 아 일치성, 그리고 장기목적에 의한 자아통제의 실용재 선택의 관점과 다르게, 소비자의 브랜드 구매의도에서 선택결정의 용 이성과 브랜드의 사용으로 느끼는 목적청취감정에 브랜드의 자아와 관련된 메시지에서 지각되는 자아입증성과 자아향상성 의 긍정적인 영향을 식별하였다. 또 이 긍정적 효과에서 사전 에 느낀 프라이드의 유형의 조절효과를 탐색하여, 브랜드 마케 팅에서 소비자가 사전에 느낀 프라이드의 유형로 서로 다른 자아유형의 메시지에 의한 접근을 하여, 이론의 발전에 기여하 고 있다.

그리고 이 연구의 결과는 마케터가 사전에 느낀 프라이드의 유형이 서로 다른 소비자에게 어떤 자아유형의 메시지로 접근 해야 자신의 브랜드를 구매하도록 설득하는가에 대한 시사점 을 제시한다. 마케터는 사전에 오만성 프라이드를 느낀 소비자 에게 소비자의 안정적인 자질을 탐구하고 자질에 의한 성공이 반영된 자아입증성 브랜드 메시지를 개발하여 소구해야 자신 의 브랜드의 구매의도를 높일 수 있다. 따라서 마케터는, 소비 자가 사전에 오만성 프라이드를 느낀 경우에, 선택결정의 용이 성과 브랜드의 사용으로 느끼는 목적청취감정을 촉진하여 자 신의 브랜드에 대한 구매의도 수준을 높이기 위해, 브랜드의 사용에서 자아를 입증할 수 있는 소비자의 능력 지능 또는 파 워 등의 개념을 사용하여 메시지를 개발하고 소구해야 한다.

그런데 소비자가 사전에 진정성 프라이드를 느낀 경우에 브 랜드의 사용에서 자아를 향상시킬 수 있는 메시지를 개발하여 소구해야 자신의 브랜드에 대한 구매를 촉진할 수 있는 목적 청취감정을 유도할 수 있다. 따라서 마케터는 사전에 진정성 프라이드를 느낀 소비자에게 자신의 브랜드의 구매의도를 높 이기 위해서 소비자의 자질보다 진정한 노력, 열정, 또는 유혹 을 극복하고 시간을 투자한 의지 등에 의한 성공을 찬양하는 자아향상성 브랜드 메시지를 개발하여 소구해야 한다.

\subsection{2. 연구의 한계와 미래연구}

그런데 본 연구에는 이론적 실무적 시사점과 함께 한계점이 있다. 첫째, 사전에 느낀 진정성 프라이드와 오만성 프라이드 간에 지각되는 자아 향상성이 선택결정 용이성 정도에 미치는 영향이 차이가 없는 것을 진정성 프라이드와 자아 향상성을 병렬적 처리의 관점에서 접근하여 연구할 필요가 있음을 지적 한다. 둘째, 본 연구는 제한적인 응답자의 범위에서 가설을 검 증하였다. 학부생을 중심으로 스마트 폰을 실증대상으로 가설 을 검증하여 한계가 있다. 다양한 제품군과 연령층을 대상으로 조사하여 연구의 신뢰성을 높일 수 있는 연구의 방안이 필요 하다. 셋째, 브랜드의 구매의도에 대한 매개영향변인인 선택의 용이성과 소비목적의 달성감정에 초점을 맞추고 이 연구를 수 행하였다. 따라서 구매의도의 이면적인 관점에서 결정의 지연 과 관련된 정보의 불확실성, 브랜드 속성의 다양성 등의 변수 를 고려하지 못했다. 이에 대한 보강이 필요하다. 넷째, 본 연 구는 소비자의 개인적 자아관점에 초점을 두었다. 사회적 아이 
덴티티와 개인적 아이덴티티로 소비자의 아이덴티티를 구분하 고 타인과 공유하고 사회가 수용하는 사회적 상징연구(Choi, Xu, \& Teng, 2018; Mia, 2017; Lee, 2019)의 관점에서 접근하 는 연구도 필요하다.

\section{References}

Anderson, C. J. (2003). The psychology of doing nothing: Forms of decision avoidance result from reason and emotion. Psychological Bulletin, 129(1), 139-167.

Anderson, J. R., \& Bower, G. H. (1973). Human associative memory. Washington, DC: Winston and Sons.

Ashton-James, C. E., \& Tracy, J. L. (2012). Pride and prejudice: How feelings about the self influence judgments of others. Personality and Social Psychology Bulletin, 38(4), 446-476.

Bargh, J. A., Gollwitzer, P. M., Lee-Chai, A., \& Barndollar, K., Trötschel, R. (2001). The automated will: Nonconscious activation and pursuit of behavioral goals. Journal of Personality and Social Psychology, 81(6), 1014-1027.

Baumeister, R. F. (2008). Free will in scientific psychology. Perspective on Psychological Science, 3(1), 14-19.

Baumeister, R. F., Vohs, K. D., \& Tice, D. M. (2007). The strength model of self-control. Current Directions in Psychological Science, 16(6), 351-355.

Beer, J. S., \& Keltner, D. (2004). What is unique about self-conscious emotions? Psychological Inquiry, 15(2), 126-129.

Bettman, J. R., Johnson, E. J., Luce, M. F., \& Payne, J. W. (1993). Correlation, conflict, and choice. Journal of Experimental Psychology. Learning, Memory, and Cognition, 19(4), 931-951.

Bower, A. B. (2001). The highly attractive models in advertising and the women who loathe them: The implications of negative affect for spokesperson effectiveness. Journal of Advertising, 30(3), 51-63.

Brewer, M. B., \& Pierce, K. P. (2005). Social identity complexity and outgroup tolerance. Personality \& Social Psychology Bulletin, 31(3), 428-437.

Chernev, A. (2003). When more is less and less is more: The role of ideal point availability and assortment in consumer choice. Journal of Consumer Research, 30(2), 170-183.

Choi, N. H. (2016). The roles of two facets of environmental pride on hedonic indulgent choice. Journal of Korean Marketing Association, 31(5). 93-111.

Choi, N.-H., Xu, H., \& Teng, Z. (2018). Roles of social identity verification in the effects of symbolic and evaluation relevance on Chinese consumers' brand attitude. East Asian Journal of Business Management, 8(4). 17-27.

Coupey, E., Irwin, J. R., \& Payne, J. W. (1998). Product category familiarity and preference construction. Journal of Consumer Research, 24(4), 459-468.

Custers, R., \& Aarts, H. (2005). Beyond priming effects: The role of positive affect and discrepancies in implicit processes of motivation and goal pursuit. European Review of Social Psychology, 16(8), 257-300.

Dijksterhuis, A., Smith, P. K., van Baaren R. B., \& Wigboldus, D. H. J. (2005). The unconscious consumer: Effects of environment on consumer behavior. Journal of Consumer Psychology, 15(3), 193-202.

Etkin, J., \& Ghosh, A. P. (2018). When being in a positive mood increases choice deferral. Journal of Consumer Research, 45(1), 208-225.

Fishbach, A., Friedman, R. S., \& Kruglanski, A. W. (2003). Leading us not into temptation: Momentary allurements elicit overriding goal activation. Journal of Personality and Social Psychology, 84(2), 296-309.

Fishbach, A., Shah, J. Y., \& Kruglanski, A. W. (2004). Emotional transfer in goal system. Journal of Experimental Social Psychology, 40(6), 723-738.

Forgas, J. P. (2001). Introduction: affect and social cognition. In Joseph P. Forgas ed. Handbook of Affect and Social Cognition(pp.1-24.), Mahwah, NJ: Erlbaum.

Gailliot, M. T., Gitter, S. A., Baker, M. D., \& Baumeister, R. F. (2012). Breaking the rules: Low trait or state self-control increases social norm violations. Psychology, 3(12), 1074-1083.

Gorn, G. J., Pham, M. T., \& Sin, L. Y. (2001). When arousal influences ad evaluation and valence does Not (and vice versa). Journal of Consumer Psychology, 11(7), 43-55.

Graeff, T. R. (1996). Image congruence effects on product evaluations: The role of self-monitoring and public/private consumption. Psychology \& Marketing, 13(5), 481-499.

Hayes, A. F. (2013). Introduction to Mediation, Moderation, and Conditional Process Analysis, New York, NY: Guilford.

He, H., \& Mukherjee, A. (2007). I am, ergo I Shop: Does Store Image Congruity Explain Shopping Behaviour of Chinese Consumers? Journal of Marketing Management, 23(5/6), 443-460.

Higgins, E. T. (1987). Self-discrepancy: A theory relating self and affect. Psychological Review, 94(3), 319-340.

Hosany, S., \& Martin, D. (2012). Self-image congruence in consumer behavior. Journal of Business Research, 65(5), 685-691.

Hoyer, W. D., Maclnnis, D. J., \& Pieters, R. (2018). Consumer behavior (7th ed). Boston, MA: Cengage learning.

Jamal, A., \& Al-Marri, M. (2007). Exploring the effect of self-image congruence and brand experience on satisfaction: The Role of expertise. Journal of Marketing Management, 23(7/8), 613-629. 
Kruglanski, A. W., Shah, J., Fishbach, Y. A., Friedman, R., \& Chun, W. Y., \& Sleeth-Keppler, D. (2002), A theory of goal systems. In Mark P. Zanna(ed.), Advances in Experimental Social Psychology, Vol. 34 (pp.331-378), San Diego, CA: Academic Press.

Lee, C-S. (2019). The effects of traditional market support projects and competition intensity of stores on store sales and number of visitors. Journal of Distribution Science, 17(3), 97-106.

Lewis, M. (2016). Self-conscious emotions: Embarrassment, pride, shame, guilt, and hubris. In L. F. Barret, M. Lewis, and J. M. Haviland-Jones(Eds.), Handbook of emotions(4th ed.)(pp.792-814), New York, NY: Guildford.

Loewenstein, G., Weber, E., Hsee, C. K., \& Welch, N. (2001). Risk as feelings. Psychological Bulletin, 127(2), 267-286.

Lurie, N. (2004). Decision making in information-rich environments: The role of information structure. Journal of Consumer Research, 30(3), 473-486.

Mandel, N., Rucker, D. D., Levav, J., \& Galinsky, A. D. (2017), The compensatory consumer behavior model: How self-discrepancies drive consumer behavior. Journal of Consumer Psychology, 27(1), 133-146.

Marshall, R., Na, W., State, G., \& Deuskar, S. (2008). Endorsement theory: How consumers relate to celebrity models. Journal of Advertisement Research, 48(4), 564-572.

Mazodier, M., \& Merunka, D. (2012). Achieving brand loyalty through sponsorship: The role of fit and self-congruity. Journal of the Academy of Marketing Science, 40(6), 807-820.

Mia, M. A. (2017). An overview of the microfinance sector in Bangladesh. East Asian Journal of Business Management, 7(2), 31-38.

Muraven, M., Tice, D. M., \& Baumeister, R. F. (1998). Self-control as a limited resource: Regulatory depletion patterns. Journal of Personality and Social Psychology, 74(3), 774-789.

Oyserman, D. (2009). Identity-based motivation: Implications for action-readiness, procedural readiness, and consumer behavior. Journal of Consumer Psychology, 19(3), 250-260.

Park, J. J., \& Sela, A. (2018). Not my style: Why affective decision makers are reluctant to make financial decisions. Journal of Consumer Research, 45(2), 298-319.

Reed II, A., Forehand, M. R., Puntoni, S., \& Warlop, L. (2012). Identity-based consumer behavior. International Journal of Research in Marketing, 29(4), 310-321.
Rosenberg, M. (1979). Conceiving the self. New York, NY: Basic books.

Sedikides, c., \& Greg, A. P. (2008). Self-enhancement: Food for thought. Perspectives on Psychological Science, 3, 102-116.

Sela, A., \& Shiv, B. (2009). Unraveling priming: When does the same prime activate a goal versus a trait? Journal of Consumer Research, 36(10), 418-433.

Sirgy, M. J., Grewal, D., Mangleburg, T. F., Park, J.-O., Chon, K.-S., Claiborne, C. B., Johar, J. S., \& Berkman, H. (1997). Assessing the predictive validity of two methods of measuring self-image congruence. Journal of the Academy of Marketing Science, 25(3), 229-241.

Spears, N., \& Singh, S. N. (2004). Measuring attitude toward the brand and purchase intentions. Journal of current issues \& research in advertising, 26(2), 53-66.

Suls, J., Lemos, K., \& Stewart, H. L. (2002). Self-esteem, construal, and comparisons with the self, friends, and peers. Journal of Personality and Social Psychology, 82(2), 252-261.

Swann Jr, W. B., Chang-Schneider, C., \& McClarty, K. L. (2007). Do people's self-views matter? Self-concept and self-esteem in everyday life. American Psychologist, 62(2), 84-94.

Swann Jr, W. B. (1983). Self-verification: Bringing social reality into harmony with the self. Social psychological perspectives on the self, 2, 33-66.

Tice, D. M., \& Masicampo, E. J. (2008). Approach and avoidance motivation in the self-concept and self-esteem. In A. J. Elliot(ed.), Handbook of Approach and Avoidance Motivatio (pp. 505-519), New York, NY: Psychology press.

Tracy, J. L., Cheng, J. T., Martens, J. P., \& Robins, R. W. (2011). The affective core of narcissism: Inflated by pride, defaulted by shame. In W. Keith Campbell, \& Joshua Miller (eds.), Handbook of narcissism and narcissistic personality disorder(pp.330-343), New York, NY: Wiley.

Tracy, J., L., \& Robins, R. W. (2014). Conceptual and empirical strengths of the authentic/hubristic model of pride. Emotion, 14(1), 33-37.

Tracy, J. L., \& Robins, R. W. (2004). Putting the self into self-conscious emotions: A theoretical model. Psychological Inquiry, 15(2), 103-125.

Tracy, J. L., \& Robins, R. W. (2007). The psychological structure of pride: A tale of two facets. Journal of Personality and Social Psychology, 92(3), 506-525.

Usakli, A., \& Baloglu, S. (2011). Brand personality of tourist destinations: An application of self-congruity theory. Tourism Management, 32(1), 114-127. 